\title{
Suptypes of JIA have different susceptibility for developing pain amplification syndrome
}

\author{
N Draheim, J Reckzeh, L Croce, R Häfner, E Schnöbel-Müller, JP Haas \\ From 18th Pediatric Rheumatology European Society (PReS) Congress \\ Bruges, Belgium. 14-18 September 2011
}

\section{Background}

Primary pain amplification syndrome (PAS [Juvenile fibromyalgia]) is an important differential diagnosis in patients suspected to have JIA. Secondary PAS may occur within the course of JIA after remission.

\section{Aim}

Characterizing the occurrence of JIA in a group of patients suffering from PAS.

\section{Methods}

Retrospective analysis in 319 patients with PAS admitted to our unit for chronic pain in 2010. Patients ' medical histories have been worked up concerning chronic inflammatory diseases. The observed frequencies of JIA subtypes have been compared to frequencies recorded by the national German registry for rheumatic diseases (Deutsches Rheumaforschungszentrum DRFZ 2008).

Table 1

\begin{tabular}{lllll}
\hline & $\begin{array}{l}\text { Number } \\
\text { observed }\end{array}$ & $\begin{array}{l}\% \\
\text { observed }\end{array}$ & $\begin{array}{l}\text { Number } \\
\text { expected }\end{array}$ & $\begin{array}{l}\% \\
\text { expected }\end{array}$ \\
\hline Oligo-JIA & 20 & 33 & 32 & 53 \\
\hline Poly-JIA & 23 & 38 & 9 & 14 \\
\hline Psoriasis-JIA & 11 & 18 & 5 & 8 \\
\hline $\begin{array}{l}\text { Entesitis } \\
\text { associated-JIA }\end{array}$ & 6 & 10 & 7 & 11 \\
\hline Systemic JIA & 1 & 1,5 & 4 & 6 \\
\hline
\end{tabular}

* Correspondence: haas.johannes-peter@rummelsberger.net Deutsches Zentrum für Kinder- und Jugendrheumatologie, GarmischPartenkirchen, Germany

\section{Results}

The medical history reported JIA in 61 patients (19\%) and chronic multifocal osteomyelitis (CRMO) in $9(3 \%)$ of the patients. (Table 1).

More than one third of the histories were not conclusive for the diagnosis of JIA according to the ILAR criteria, mainly because arthritis had not been assured to be present for more than 6 weeks.

\section{Conclusion}

Polyarticular and Psoriasis JIA seem to have an increased risk to develop secondary PAS. Primary PAS has to be suspected in a number of patients diagnosed as PAS secondary to JIA as arthritis never had been proven conclusively. There are a remarkable number of CRMO patients within the group of secondary PAS patients.

Published: 14 September 2011

doi:10.1186/1546-0096-9-S1-P222

Cite this article as: Draheim et al.: Suptypes of JIA have different susceptibility for developing pain amplification syndrome. Pediatric Rheumatology 2011 9(Suppl 1):P222.

Submit your next manuscript to BioMed Central and take full advantage of:

- Convenient online submission

- Thorough peer review

- No space constraints or color figure charges

- Immediate publication on acceptance

- Inclusion in PubMed, CAS, Scopus and Google Scholar

- Research which is freely available for redistribution

\section{Biomed Central}

